\title{
Sitting an Exam from the Students' Point of View
}

\section{Jana Matošková}

\begin{abstract}
The study examined students' reports about their feelings related to exams, factors influencing exam passing and behaviour and mental strategies applied during exam sitting. It was based on an analysis of data gained by way of interviews and group discussions with students, a questionnaire survey among students and student seminar works. The study supports the idea that academic performance is influenced by external context as well as internal factors like intelligence, personality, and study motivation. The study indicates that students prefer neither a surface approach to studying nor cheating, but there are exceptions in which they find such behaviour appropriate. Further, if students have lack of knowledge, they often rely in such cases on an examiner's exhaustion, lack of attention or indulgence.
\end{abstract}

Keywords: university student; behaviour strategy; exam; cheating; academic performance.

\section{Účast na zkoušce z pohledu studentů}

\begin{abstract}
Abstrakt
Tato studie zkoumá výpovědi studentů o jejich pocitech ohledně zkoušek, faktorů, které podle nich ovlivňují úspěšné složení chování, a strategií myšlení a chování, které aplikují během zkoušky. Studie je založena na analýze dat získaných prostřednictvím rozhovorů
\end{abstract}


a skupinových diskusí se studenty, dotazníkového šetření mezi studenty a studentských seminárních prací. Studie podporuje myšlenku, že studijní výkon je ovlivněn externím prostředím i interními faktory jsou jakou inteligence, osobnost a motivace ke studiu. Studie naznačuje, že studenti nepreferují ani povrchový př́stup ke studiu, ani podvádění. Nicméně existují výjimky, které podkládají takové chování za vhodné. Pokud studenti nejsou dostatečně na zkoušku naučeni, spoléhají na to, že vyučující bude unavený, nebude dávat pozor či že budou shovívaví.

Klíčová slova: student univerzity; strategie chování; zkouška; podvádění; studijní výkon.

\section{Introduction}

Exams aim to assess primarily the level of preparation reached by the students (Frosini, Lazzerini, \& Marcelloni, 1998). On the other hand, exams typically belong to critical and stress-related situations with which students are regularly confronted. Spangler et al. (2002) explain that passing or failing exams may profoundly affect their chances to get access to further educational and occupational development, thus implying high importance and the potential to induce high amounts of psychological stress. In addition, as Pressley et al. (1997) note, getting ready for an exam might sometimes be difficult because of unsuitable textbooks, inadequate teaching, failures to specify testing demands, reading strategy deficiencies, background knowledge deficiencies, appropriate information processing deficiencies, anxiety or low motivation. That is why academic exams still awake research interest.

Many studies have dealt with predictors of academic performance (e.g., Caprara, Vecchione, Alessandri, Gerbino, \& Barbaranelli, 2011; Krumm, Lipnevich, Schmidt-Atzert, \& Bühner, 2012; Win \& Miller, 2005; Zuffianò et al., 2013) or on strategies for exam preparation (Halamandaris \& Power, 1999; Mirkov, 2010; Neuderth, Jabs, \& Schmidtke, 2009). Some studies focused on cheating at exams, e.g. Tibbetts (1999). However, only a few studies have examined exams from students' points of view and dealt with their recommendations for exam passing. Therefore, the goal of this study was to detail university students' beliefs about the examinations they face. Specifically, the study examined students' reports about factors influencing passing an exam, and the behaviour and mental strategies that students mentioned in relation to it. The students' point of view on exam passing was chosen because, as Van Etten, Freebern, and Pressley (1997) note, students have their own understandings about their academic world and knowledge of the conscious decisions they must make to negotiate the academic demands on them. Therefore, there might appear more factors critical in exam passing and different strategies than the ones emphasized in the studies to date. Answers to following questions were sought within the data analysis: 1) What feelings do university students 
have about exams?; 2) What internal and external factors influencing exam passing do students mention in their comments?; 3) What behaviour and mental strategies do students present for exam passing?

\section{Theoretical Framework}

Aitken (1982) defines academic performance as a function of intellectual ability, the level of student motivation, academic skills, the quality of the physical environment in which the student's academic work is done, the degree of family support for the student completing a university education, the degree of peer group support for intellectual and academic activities, faculty teaching ability, the degree of close personal contact with faculty, student satisfaction with major field of study, the health of the student and the possible intervention of external factors (such as severe personal injury or illness, or family or personal problems). Generally, personal predictors of academic performance are typically dichotomized into cognitive characteristics (e.g., mental speed, working memory) and non-cognitive characteristics such as consciousness or motivation (Krumm et al., 2012). For example, Caprara et al. (2011) supposed that it is likely that conscientious students perform better because of their ability to make plans, regulate their behaviour in accordance to their purposes, make the effort that is needed to learn and demonstrate persistence.

Generally, as an exam is a stressor for many students, students apply some coping strategies to deal with it. Three main coping strategies as individual response tendencies to stressors might be distinguished: problem-focused, emotional-focused and avoidant (see e.g. Halamandaris \& Power, 1999; Spangler et al., 2002). Problem-focused coping (i.e. coping with the problem that is causing the distress) means that students can try to reduce exam-related stress and meet academic demands by using personal and social resources like investing effort, asking for instrumental help, finding out more information about the exam or making up a list of priorities for tackling the exam. Emotionalfocused coping (i.e. focused on regulating emotion) might include activities like trying not to feel angry or depressed or daydream about the future, to change appraisals (e.g. positive reinterpretation) or to use methods of relaxation. Spangler, Pekrun, Kramer, and Hofmann (2002) state that problem-focused coping may be specifically adaptive during preparation; emotions-focused coping may be helpful for emotional regulation during the exam. The third coping is avoidant coping. It would imply withdrawal from the situation psychologically (e.g. by ignoring academic demands, keeping negative emotions out of consciousness) or behaviourally (e.g. by reducing effort, not entering the exam) - which in fact may increase psychological stress rather than reduce it.

Some studies and monographs discuss in detail suitable strategies which a student should apply during an exam to achieve success, e.g. Fryjaufová (2006), Jacobs and 
Hyman (2010), Price and Maier (2010), Robinson (1993). For example, a student should think positively, read the instructions of written exam tests carefully, leaf though the test to get an overall sense of the questions and their difficulty, pay close attention to any key words in the question, start with questions which he/she can answer well and if he/she does not know the exact answer, to write down his/her best approximation.

Regarding learning, some authors (e.g. Davidson, 2002) highlight that students use two basic study approaches - a "surface" study approach or a "deep" study approach. The first one means students concentrate on detailed parts of the text in sequence without regard to the importance of these passages. The latter means that students attempt to understand the meaning of the article and the broader implications of the message contained in the text. It is assumed that a "deep" study approach is necessary for the achievement of a more conceptual form of learning.

Tibbetts (1999) and Van Etten et al. (1997) mention that recent studies have found that test cheating is common among college students. In relation to a student's cheating, rational choice models of behaviour are mentioned. The basic idea of such a model is that individuals are rational actors who tend to behave according subjective evaluations about expected costs and benefits related to a given act (Tibbetts, 1999).

\section{Methods and Participants}

The study is based on data gathered during a research focused on the tacit knowledge of university students. Research participants were full-time students, especially Bachelor's and Master's students, and three graduates from the same university. Methods of non-probability sampling - intentional (simple), opportunistic and self-selection - were used to select the respondents in the research.

Participants were from one university. The semester is 13 or 14 weeks long (depending on the faculty), then an exam period follows. The regular exam period usually has five weeks. Students commonly have 3 chances to pass an exam (one regular attempt and two retakes).

Not all subjects are officially finished by a final exam, but it is common that at least a passing of a final written test is required in the case of credit courses as well. Normally students have 2 chances to pass the test for gaining a credit course. Considering subjects at Faculty of Management and Economics, the most difficult subjects for students might be Mathematics, Macroeconomics, Microeconomics and Business Economics. 


\subsection{Procedure}

Compliance with ethical research rules, especially informing respondents sufficiently and safeguarding anonymity during evaluation, was ensured during the data collection. As the primary research focused on the development of an inventory of tacit knowledge measurement, data gathered during research was re-analysed for this study. Specifically, quotations related to sitting university exam and factors which influence exam passing were found. Regarding the topic, the following sets of data gathered during the research were identified to be relevant:

- Transcriptions of three group discussions focused on outlining criteria for evaluating student success and setting examples of tacit knowledge important for student success:

- with five full-time students from the Faculty of Management and Economics (GD-S);

- with three full-time post-graduate students from the Faculty of Management and Economics (GD-PGS);

- with three graduates of the Faculty of Management and Economics (GD-G).

- Transcription of a workshop with students utilising a follow-up discussion (W-CS) Twelve full-time students participated in the workshop. The students were divided into two groups. The groups' task was to suggest critical situations in the life of a university student. A moderated group discussion followed the group work, during which the students were to suggest appropriate and inappropriate behaviour strategies in chosen, previously defined, critical situations.

- 217 students' responses from a questionnaire survey filled in by university students (Q) - full-time students of five university faculties participated in the questionnaire survey and in total 985 questionnaires were filled out. The priority groups for distributing the questionnaire to were the first year students of bachelor and master degree studies. They filled out the questionnaire during their seminars and tutorials. The topics at which the questionnaire aimed were: 1) characteristics and behaviour of successful university students, 2) recommendations for best friends at the beginning of the study program to make that friend's studies effective, 3) situation in which tacit knowledge might be relevant.

- Transcriptions of 21 semi-structured interviews (I) with students who were identified as successful students by their peers in a previous questionnaire survey amongst the students were representatives of five different university faculties. The methodology prepared for the interviews aimed at students' thinking, behaviour, experience and critical situations in the life of a student.

- Two students' seminar papers (SP) on the topic of "Situations in the life of a university student and their management strategies" - the students' task was to define, based on their own experience, critical situations in the life of a student and for each of those situations to suggest appropriate and inappropriate management 
strategies. Both students presenting their work were from the Faculty of Management and Economics.

\subsection{Data Analysis}

During the data re-analysis, sections in documents which bore information about sitting an exam and factors influencing exam passing were found. Then initial themes in data were identified, namely feelings about exams, factors influencing passing an exam and the student's behaviour strategies related to an exam. Next, the data was sorted by theme and a thematic chart was done. After that a descriptive analysis with data categorization followed. Finally, data summarising was done.

\subsection{Results}

At last five broad themes emerged from the analysis: feelings about exams, external and internal factors influencing passing an exam, student's behaviour strategies before an exam, student's behaviour strategies during an exam and student's strategies of dealing with lack of knowledge during an exam (including cheating at exams).

\subsubsection{Feelings about Exams}

The first identified topic was feelings about exams. Some students are aware that, in the long-term, passing exams is imperative to graduating from their chosen university. Additionally, indices that exams are a way of preparation for student's future professional life were found. Specifically, it was mentioned that exams teach how to deal with unpredictable situations (to improvise), to communicate, to find out and process information. As well remarks about a relation between exams and self-development were found. Moreover, some felt that sitting an exam is a critical situation connected with stress. However, others considered that an exam should not be viewed as a makeor-break and key point in one's life.

'what we shouldn't do is to pretend that it [exam] is some kind of milestone in one's life, that it represents some kind of success or failure and - stress out because of it all the time' 126

\subsubsection{Factors Influencing Passing an Exam}

The second topic was factors influencing student behaviour at an exam and the exam result. An overview of the factors mentioned by participants is presented in Figure 1. First, there are some external circumstances which should be taken into account. For 
example, the subject itself (especially its supposed difficulty) and its teacher (his/her attitude to students, style of teaching and his/her fatigue caused by students' examination). Furthermore, participants admitted that also the number of exam chances matters. Generally, they have three chances to pass an exam. The more unsuccessful chances they have had, the more intensive preparation for the exam is. Sometimes also luck on exam questions can help in exam passing.

'As the tests and questions are...made as they are, sometimes luck is needed because one can't know everything $100 \%$.' 125

Additionally, some note that friends and acquaintances can help. Specifically, it was mentioned that friends' experience can influence stress related to the exam. As well, friends and acquaintances can be sources of information about the teacher and the exam. On the other hand, a lot of factors influencing exam passing are internal. Such factors are related to a student's personal characteristics and his/her behaviour.

Personal characteristics which might make an exam easier were identified as follows: 1) attitudes to study and with it related motivation (especially student's interest about the subject and the supposed importance of the subject for future career), 2) intelligence, 3) student's knowledge, skills and experience, 4) student's traits like endurance, ambitiousness, purposefulness, self-confidence, proactivity, flexibility and courage. Intelligence might matter especially in cases when to learn by heart is not enough to pass an exam (e.g., in subjects where graphs or arithmetical problems are common) or when the student has to improvise because of the lack of knowledge.

A student's knowledge, skills and experience influence his or her behaviour before the exam (especially the intensity of preparation and the choice of strategies used for it), as well as during the exam when dealing with the lack of knowledge. Specifically, general knowledge and personal experiences (e.g., from part-time work) with the subject content might be welcomed in cases where it is necessary to improvise. Moreover, three type of skills and abilities seem to be essential: 1) self-management, 2) decision-making (the ability to decide in time and choose the right possibility) and 3) communication and social skills. Self-management influences above all preparation for an exam. It includes at least time management (abilities to plan preparation, to set priorities), self-organisation and self-motivation and an ability to cope with stress. It was mentioned several times that a student should try to stay calm and try to think positively during exam preparation and during the exam itself - as well as in cases the student finds out that he/she lack some knowledge during the exam.

'One has to take it [exam] easy and not to stress out. It's not worth getting health problems.' GD-PGS 
Communication and social skills are related to verbal communication (vocabulary, fluency and readiness for communication) as well as non-verbal communication (including care of appearance). Participants stated that communication and social skills can be helpful in cases the student wants to mask his/her lack of knowledge during the exam, to get a teacher's help, to persuade the teacher about student's interest in the subject or to awake someone's interest in something.

\section{Figure 1}

Factors influencing an exam result

\section{Circumstances}

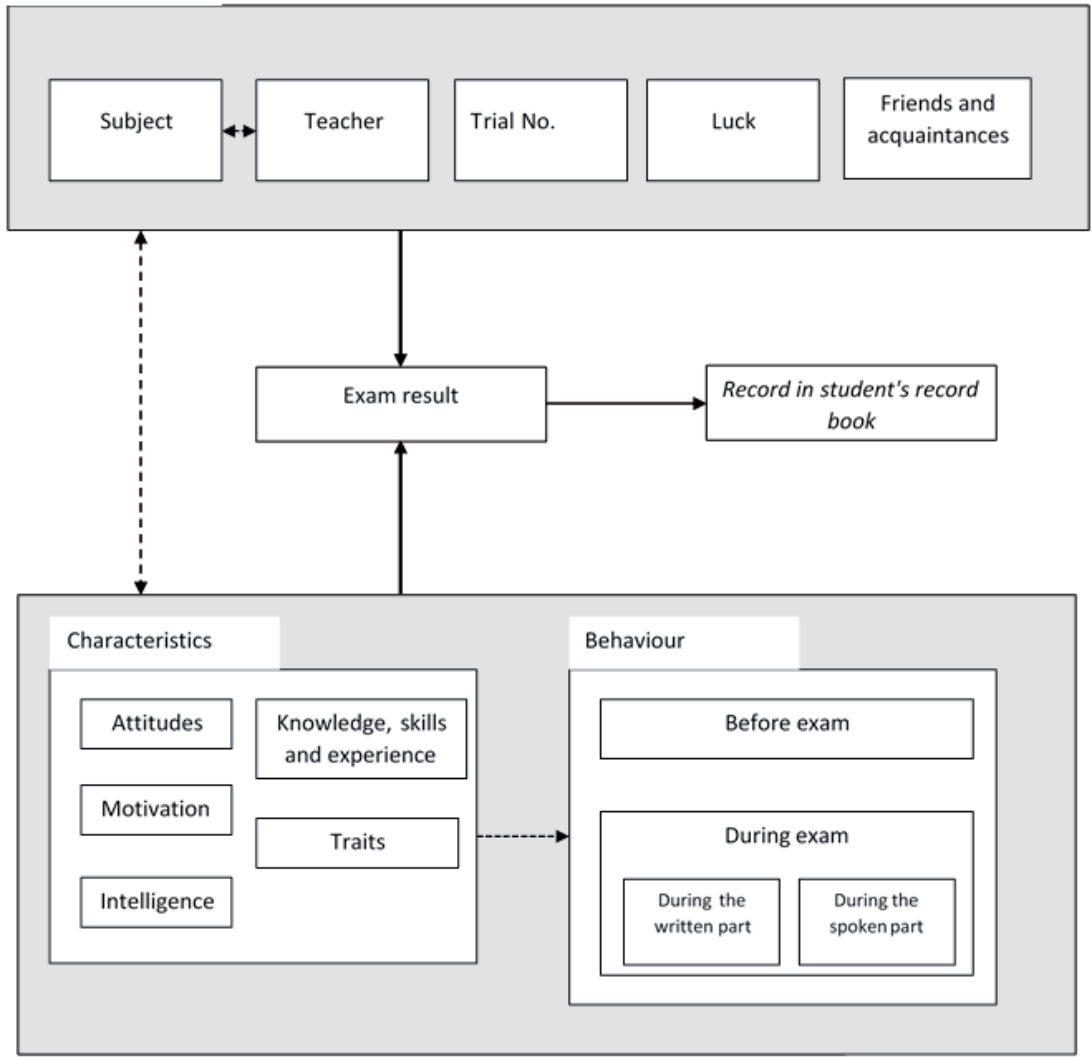

Student 


\subsubsection{Student's Behaviour Strategies before an Exam}

The third topic identified was the student's behaviour before exam. In this case, the most mentioned strategies were connected with preparation for the exam. Specifically, the following actions were stated: 1) to attend lectures during the term, because it is helpful for future preparation, 2) to make a social network, because friends and acquaintances can be sources of useful information (about the teacher and the exam itself), 3) to make a plan of preparation, which means among others to decide which exam term to attend (the findings indicate that students prefer to go as soon as possible or as late as possible), to set priorities (school versus entertainment) and to register for the exam and 4) to learn. The last named is related to a decision what in particular to learn might be important, and to concentrate on it where it is possible to imagine oneself as a teacher and so to gain a new point of view on the subject content. Furthermore, it was mentioned that it is not the best strategy to learn everything by heart but rather to think about the subject matter and look for some logical connections. Generally, a frequent comment was that the student should stay calm and keep on the top of things. If the student is not enough learned and the exam term is soon, two possible preferred strategies were identified: to withdraw from the exam term or to prepare a cheat sheet. Additional advice which could be derived from participants' statements is to limit alcohol consumption the night before the exam term, to check the time and place of the exam and to sort out the means of transport which will minimise the chances of delay and arriving late for the exam. Even then, it was advised to allow extra time.

\subsubsection{Student's Behaviour Strategies during an Exam}

As explained earlier, a student's behaviour during the exam might influence the exam result. Again, the advice of staying calm and keep on the top of things appeared. It is essential especially when a student finds out that he/she lacks the knowledge to answer everything. Other basic recommendations are to think, not to look for complicatedness and trickiness in instructions and to make the effort to formulate one's ideas and knowledge in answers as comprehensibly and precisely as possible. There is some evidence to suggest that students prefer not to cheat at exam.

'...he [a successful student] doesn't cheat during tests because he knows that it won't help him to gain better skills.' Q966

Since an exam can be written, oral or have both parts, some statements connected with particular exam parts were identified. Regarding a written exam, it was stated to read instructions carefully and just to be sure, to sit next to a well-prepared fellow student. At a written exam it is also advisable to set priorities when answering questions, which means to plan time for answering individual questions, deciding which questions to 
answer first and thinking about the answers before writing them down. As far as an oral exam is concerned, the basic recommendation is probably to speak - optimally to the point.

'... I say to myself, better keep on talking even if not all of it may be correct rather than being quiet.' GD-G

Interestingly, some remark that it is worthwhile to guess the examiner's expectations and requirements as well as to assess the examiner's mood and then to behave in accordance with it. Some participants argue that it is beneficial to present good manners and to act confidently. Intriguingly, advice to attend an oral exam as one of the first students on a given exam day appeared, which might be connected with an assumption that the examiner might have a better mood at the beginning and a chance that the student will succeed is bigger.

\subsubsection{Strategies of Dealing with Lack of Knowledge during an Exam}

The fifth theme which came up was dealing with a lack of knowledge. The basic remark to this topic was that such a thing is common and that is why a student should expect it could happen. A common view was that it is better to stay calm and not to reveal the lack of knowledge. Next, it seems advisable to assess a risk related to cheating. 'I have to foresee whether a teacher can see me fiddling with the test.' Q807

If risk of getting caught is low, it is possible to try cheating (e.g., to use a cheat sheet or a mobile phone). A student stated that it is a good idea to try to excuse oneself, go to toilet and then call a friend from there and ask him to find out the answer. Another student admitted that apart from other things, he keeps cheat sheets in his mobile phone.

However, if a student cheats, it is still necessary to suppose the examiner might discover it and thus, in such a situation, should stay calm and to try to find out another solution. One participant suggested to borrow a cheat sheet from his fellow student. If consequences of cheating could be serious or the risk of being caught cheating is high, it is still possible to improvise. This means 1 ) to think and try to derive the answer with the use of other knowledge, general knowledge, own personal experience and/ or logical thinking, 2) to describe an example or an application if suitable, 3) to answer to something else with a hope the examiner would not notice that the answer is not in accordance with the instruction. Regarding written exams, it might be beneficial to flip through the test (maybe something useful or inspiration can be found in instructions to other questions), to read instructions carefully (because there might be a hint to the answer) or in the case of a test with offered answers (e.g. A, B, C...) it is possible to just guess. As far as an oral exam is concerned, essential tips are 'to speak and speak' and listen to the examiner carefully, because he/she can offer a clue. 
'I've been at an exam with a mate who didn't understand the topic at all. But he can speak so well that he basically convinced the teacher that he understood it even though he knew nothing.' 108

'If one isn't sure what is exactly meant by a question at an exam, he has to listen to a professor and improvise accordingly.' Q852

\section{Discussion and Conclusion}

The study deals with students' understanding about their academic world. The aim of the study was to look for answers to the following questions: 1) What feelings do university students have about exams?; 2) What internal and external factors influencing exam passing do students mention in their comments?; 3) What behaviour and mental strategies do students present for exam passing?

Generally, the results from the current study are consistent with previous findings. Students reported that a difficult exam can be a stressful situation for them. This is in accordance with the findings of Spangler et al. (2002) who found out that before the exam, when students still are experiencing uncertainty about actual demands and the course of the exam, negative emotions seem to be most prominent. On the other hand, some students are aware that exams are useful for their future professional life.

The study also replicated the influence of other factors previously documented to influence academic performance. Most of factors which Aitken (1982) defined as influencing academic performance were mentioned by students as well. In connection with the findings of Van Etten et al. (1997) about factors affecting test preparation, examination experiences seem to be relevant not only for test preparation but also for exam passing itself. Moreover, the study findings further support the idea that academic performance is influenced by intelligence, personality and study motivation. One interesting finding is some students' confessions that the number of unsuccessful exam chances from the subject matters in their study effort.

It is encouraging that students' notes about what to do to pass an exam are in accordance with statements in literature. Participants stated problem-focused coping strategies as well as emotional-coping ones. Furthermore, the study indicates that students prefer neither the surface approach to studying nor cheating. On the other hand, there seem to be some exceptions and the further research could examine such exceptions more deeply. One interesting finding were students' comments about the reduction of alcohol consumption the night before the exam, which raises the question of how common it is to drink alcohol or to use other addictive drugs for university students. This is another topic which might be further examined. 
The study extends the knowledge of students' strategies to deal with a lack of knowledge during an exam. The findings suggest that students often rely in such cases on an examiner's exhaustion, his/her lack of attention and/or indulgence.

The study has several practical implications. First, as self-management, decisionmaking skills and communication and social skills were mentioned to be important for academic success, it strengthens the idea that such skills need to be developed in university students from their first months in an academic setting. For example, seminar tasks could support such skills development, or extra-curriculum courses could be offered to students. Furthermore, as the role of teacher is appreciable, good teaching skills seem to be necessary, as well as reducing student anxiety and maintaining and enhancing student motivation which Pressley et al. (1997) mention as well. Another important practical implication is connected with discouraging students from cheating. As Tibbetts (1999) suggests, the existence of an official honour code and the consistent referral to an official zero-tolerance policy toward cheating and a clear explanation of why these acts constitute immoral behaviour by teachers and administrators would be a significant step toward reinforcing student's moral beliefs regarding acts of cheating.

A limitation of this study is that it represents the perceptions of students at one university. On the other hand, several methods of data collection were used. Another limitation of the study is that secondary data analysis were used, because the data was collected originally for another purpose. Thus it was not possible to give additional questions to find out more details. A further limitation of the study is that students' ability to give recommendations (to describe a strategy for passing exams) does not mean that they apply the strategies into practice themselves. For example, Yazedjian et al. (2008) found that although students reported numerous strategies they believed would help them to be successful, many responded that they did not necessarily employ those strategies.

\section{Acknowledgements}

This contribution was written within the framework of the GA $\check{C} R$ (Czech Science Foundation) grant-maintained project:Reg. No. 407/12/0821, Creating a Czech Instrument for Measuring Academic Tacit Knowledge, and with the financial support of GA ČR. 


\section{References}

Aitken, N. D. (1982). College Student Performance, Satisfaction and Retention: Specification and Estimation of a Structural Model. The Journal of Higher Education, 53(1), 32-50, https://doi. org/10.2307/1981537.

Caprara, G. V., Vecchione, M., Alessandri, G., Gerbino, M., \& Barbaranelli, C. (2011). The contribution of personality traits and self-efficacy beliefs to academic achievement: A longitudinal study. British Journal of Educational Psychology, 81(1), 78-96.

Davidson, R. A. (2002). Relationship of study approach and exam performance. Journal of Accounting Education, 20(1), 29-44, https://doi.org/10.1016/S0748-5751(01)00025-2.

Frosini, G., Lazzerini, B., \& Marcelloni, F. (1998). Performing automatic exams. Computers \& Education, 31(3), 281-300, https://doi.org/10.1016/S0360-1315(98)00042-6.

Fryjaufová, E. (2006). Jak uspět na vysoké škole. Brno: Computer Press.

Halamandaris, K. F., \& Power, K. G. (1999). Individual differences, social support and coping with the examination stress: A study of the psychosocial and academic adjustment of first year home students. Personality and Individual Differences, 26(4), 665-685, https://doi.org/10.1016/ S0191-8869(98)00172-X.

Jacobs, L. F., \& Hyman, J. S. (2010). The secrets of college success. San Francisco: Jossey-Bass.

Krumm, S., Lipnevich, A. A., Schmidt-Atzert, L., \& Bühner, M. (2012). Relational integration as a predictor of academic achievement. Learning and Individual Differences, 22(6), 759-769, https:// doi.org/10.1016/j.lindif.2012.05.002.

Mirkov, S. (2010). How do learning goals and strategies influence students' academic success. Zbornik Instituta za Pedagoska Istrazivanja, 42(2), 217-231, https://doi.org/10.2298/ ZIPI1002217M.

Neuderth, S., Jabs, B., \& Schmidtke, A. (2009). Strategies for reducing test anxiety and optimizing exam preparation in German university students: A prevention-oriented pilot project of the University of Würzburg. Journal of Neural Transmission, 116(6), 785-790, https://doi. org/10.1007/s00702-008-0123-7.

Pressley, M., Yokoi, L., Van Meter, P., Van Etten, S., \& Freebern, G. (1997). Some of the Reasons Why Preparing for Exams Is so Hard: What Can Be Done to Make It Easier? Educational Psychology Review, 9(1), 1-38.

Price, G., \& Maier, P. (2010). Efektivní studijní dovednosti: odemkněte svůj potenciál. Praha: Grada Publishing.

Robinson, A. (1993). What smart students know: maximum grades, optimum learning, minimum time (1st ed). New York: Three Rivers Press.

Spangler, G., Pekrun, R., Kramer, K., \& Hofmann, H. (2002). Students' emotions, physiological reactions, and coping in academic exams. Anxiety, Stress and Coping, 15(4), 413-432, https://doi. org/10.1080/1061580021000056555.

Tibbetts, S. G. (1999). Differences between women and men regarding decisions to commit test cheating. Research in Higher Education, 40(3), 323-342.

Van Etten, S., Freebern, G., \& Pressley, M. (1997). College Students' Beliefs about Exam Preparation. Contemporary Educational Psychology, 22(2), 192-212, https://doi.org/10.1006/ceps.1997.0933.

Win, R., \& Miller, P. W. (2005). The effects of individual and school factors on university students' academic performance. Australian Economic Review, 38(1), 1-18, https://doi.org/10.1111/j.14678462.2005.00349.x.

Yazedjian, A., Toews, M. L., Sevin, T., \& Purswell, K. E. (2008). 'It's a Whole New World': A Qualitative Exploration of College Students' Definitions of and Strategies for College Success. Journal of College Student Development, 49(2), 141-154. 
Zuffianò, A., Alessandri, G., Gerbino, M., Luengo Kanacri, B. P., Di Giunta, L., Milioni, M., \& Caprara, G. V. (2013). Academic achievement: The unique contribution of self-efficacy beliefs in self-regulated learning beyond intelligence, personality traits, and self-esteem. Learning and Individual Differences, 23(1), 158-162, https://doi.org/10.1016/j.lindif.2012.07.010.

\section{Contact:}

Ing. Jana Matošková, Ph.D.

Department of Management and Marketing

Faculty of Management and Economics

Tomáš Bata University in Zlín

Mostní 5139, 76001 Zlín, Czech Republic

tel. +420 576032272

E-mail: matoskova@fame.utb.cz

Ing. Jana Matošková, Ph.D. is a Senior Lecturer in the Department of Management and Marketing in the Faculty of Management and Economics at Tomas Bata University in Zlín, in the Czech Republic. Her research interests are oriented towards the fields of Human Resource Management, Managerial Work, Career Management, Knowledge Management (especially in connection with Tacit Knowledge and Knowledge Sharing). She has participated in several scientific projects, e.g. GA ČR, 407/12/0821, Creating a Czech Instrument for Measuring Academic Tacit Knowledge and GA ČR, 406/08/0459, Developing Managerial Tacit Knowledge. 